\title{
Microbial Assessment and Sources for Contamination of Unpackaged Fruit Juice Served in Restaurants of Bushenyi-Ishaka Municipality Western Uganda
}

\author{
Theophilus Pius' ${ }^{1,2}$, Solomon A. Mbina1, Andrew Tamale1 \\ ${ }^{1}$ Department of Public Health, School of Allied Health Sciences, Kampala International University Western Campus Ishaka, \\ Bushenyi, Uganda \\ ${ }^{2}$ Department of Medical Laboratory Sciences, Kampala International University Western Campus Ishaka, Bushenyi, Uganda \\ Email: piustheophillus@kiu.ac.ug
}

How to cite this paper: Pius, T., Mbina, S.A. and Tamale, A. (2021) Microbial Assessment and Sources for Contamination of Unpackaged Fruit Juice Served in Restaurants of Bushenyi-Ishaka Municipality Western Uganda. Open Access Library Journal, 8: e8115.

https://doi.org/10.4236/oalib.1108115

Received: October 26, 2021

Accepted: November 27, 2021

Published: November 30, 2021

Copyright $\odot 2021$ by author(s) and Open Access Library Inc.

This work is licensed under the Creative Commons Attribution International License (CC BY 4.0).

http://creativecommons.org/licenses/by/4.0/

(c) (i) Open Access

\begin{abstract}
Introduction: Globally, unpackaged fruit juices are consumed daily as part of our meals or alone. Unpackaged fruit juices are juices usually served in restaurants in cups. In Bushenyi, Ishaka Municipality Uganda, the most commonly served fruit juices in restaurants are mango, passion fruit, pineapple, and watermelon. However, these juices are beneficial to consumers, their safety is of public health concern due to their suitability in supporting bacterial growth. Objective: This study assessed microbial load and sources for contamination of unpackaged fruit juices served in restaurants of Bushenyi, Ishaka Municipality. Methods: A cross-sectional was employed and unpackaged fruit juice samples were collected in a sterile universal specimen container, transported in a cold chain box to the microbiology laboratory immediately for analysis. Total bacterial load, total coliform and a structured questionnaire were used to collect data on sources for contamination. Results: This study found consistent levels of bacterial contamination range between $5.2-5.4 \mathrm{log}$ $\mathrm{CFU} / \mathrm{ml}$ with no significant differences found on day 1 and day 7 and this demonstrated constant levels of contaminants in the study areas. Contamination on day 1 and day 7 was observed in mangoes, passion, pineapples and watermelon with no significance differences. The total coliform count was in the range of $4.9-5.3 \log \mathrm{CFU} / \mathrm{ml}$ and was highest in all juices above the reference acceptable limits. Water as factor for contamination was significant at $\mathrm{p}<0.05$. The high bacterial load and fecal coliform are attributed to the use of unclean water for juice preparation. This study observed contamination with fecal coliform bacteria to be a public health concern in the study areas and
\end{abstract}


called for intensify health education among juice producers to observe safety steps during juice preparation and storage.

\section{Subject Areas}

Public Health

\section{Keywords}

Microbial, Unpackaged, Fruit, Juice, Contamination, Coliform, Bacterial, Water, Hygiene

\section{Introduction}

Fruits juices are part of our daily consumptions in all parts of the world. They are usually consumed alone or as part of most individual's diet plan which is always included as a whole juice, beverage or still drink [1]. Fruit juices contain antioxidant and essential nutrients that support health by improving the body immune system and also provide a good medium that supports bacteria and mold growth [2]. Most fruit juices contain high potassium and low sodium, a quality which helps in maintaining a healthy blood pressure; Vitamin $\mathrm{C}$ which is naturally a nutritional component of most juices is essential for the body in the formation of blood vessels, collagen, cartilage and muscle. It is also known to help in iron absorption [3]. Despite the beneficial effects of fruit juices to consumers, improper handling, poor hygiene practices and the lack of good environmental sanitation affect the quality and safety of fruit juices to consumers due to avoidable bacterial contaminations [4].

A higher microbial load above the set standard by world health organization (WHO) and other health authorities around the world has been a public health concern to juice consumers [5]. The sources of fruit juices contamination have been attributed to use of contaminated equipment, unclean water, poor personal hygiene of juice producers and lack of awareness and health education about good hygiene practices during juice preparation, storage and serving to consumers [6]. Other studies attributed the sources of contamination to location of the juice traded restaurant [7]. Study in United State of America (USA), reported a disease outbreak that was linked to consumption of fruit juices and this has been a public health concern since 1990s; The 2001-2006 disease outbreak in US was projected to cause about 1,366 illnesses with Salmonella, Escherichia coli O111 and Cryptosporidium implicated as the etiological agents [8]. In Bangladesh, a study reported dominant bacterial pathogens in fruit juice such as Escherichia coli, Pseudomonas aeruginosa, Salmonella typhimurium Proteus vulgaris Staphylococcus aureus, Klebsiella pneumoniae and Enterobacter species. All the above mentioned indicates fruit juice as potential sources of human illnesses such as diarrhea and enteric fever (typhoid) [9]. In India, a study on microbial quality 
and safety of fruits juices found bacterial contamination in sweet lemon, pineapple, pomegranate, apple, orange and mix fruit with each of them having a number of strains bacteria [10].

Furthermore, fruit juices are regarded as the most preferred non-alcoholic beverages worldwide to all age groups [11]. They are also well recognized for their nutritive values, minerals and vitamin contents [9]. However, many outbreaks of human infections have been associated with the consumption of contaminated fruit juices [12]. Pathogenic organisms can go into fruits and vegetable juice through damaged surfaces, such as punctures wounds, cuts and splits that occur during growing or harvesting [13]. The presence of bacterial pathogens in fruit juices is a public health concern because these pathogens were implicated in several outbreaks associated with fruit juices [2]. [7] suggested that regular monitoring of the quality of fruit juices for human consumption must be introduced to avoid any potential pathogen outbreaks. In Uganda, different types of fruits are grown while some are imported from neighboring countries. Passion fruit marketing is the most common with limited importation from Kenya and Rwanda [14]. Uganda National Bureau of Standards recommended the following standards for microbiological quality of fruit juices: Total bacteria count of $25 \mathrm{CFU} / \mathrm{ml}$, total coliform count of zero $\mathrm{CFU} / \mathrm{ml}$, and $E$. coli count of zero CFU/ml and pathogenic species zero CFU/ml [5]. In February 2015, UNBS reported that $60 \%$ of juice producers do not observe hygiene practices [15]. A thorough and extensive investigation of unpackaged fruit juice around the country including Bushenyi district would give an insight of bacteriological quality of juice served in restaurants. This is imperative as most people preferred to take ready to serve food including fresh unpackaged juice in restaurants during lunch hour than going home to cook and eat before going back to duty post for the rest of the day. Hence, the need for the assessment of the bacteriological quality and sources for contamination of unpackaged fruit juice was done in this study.

\section{Methods}

\subsection{Study Area}

The study was done at Bushenyi-Ishaka Municipality which is located in $\mathrm{Bu}$ shenyi district $58 \mathrm{~km}$ along Mbarara-Kasese road in western Uganda. The municipality is neighbored with sub-counties of Bugarama, Kashenyi, Kayanta, Kitojo, Kyamumari and Makota. The district is bordered by Rubirizi to the NorthWest, Buhweju district to the North-East, Sheema district to the East and Mitooma district to the South. Bushenyi-Ishaka Municipality is a fast growing district with human population of about 41,063 people [16], and has many restaurants. A high consumption rate of unpackaged fruit juice is due to low purchasing power. The people of the district are low income earners and are engaged in crop agriculture, dairy farming, trading and cattle rearing [Figure 1]. 


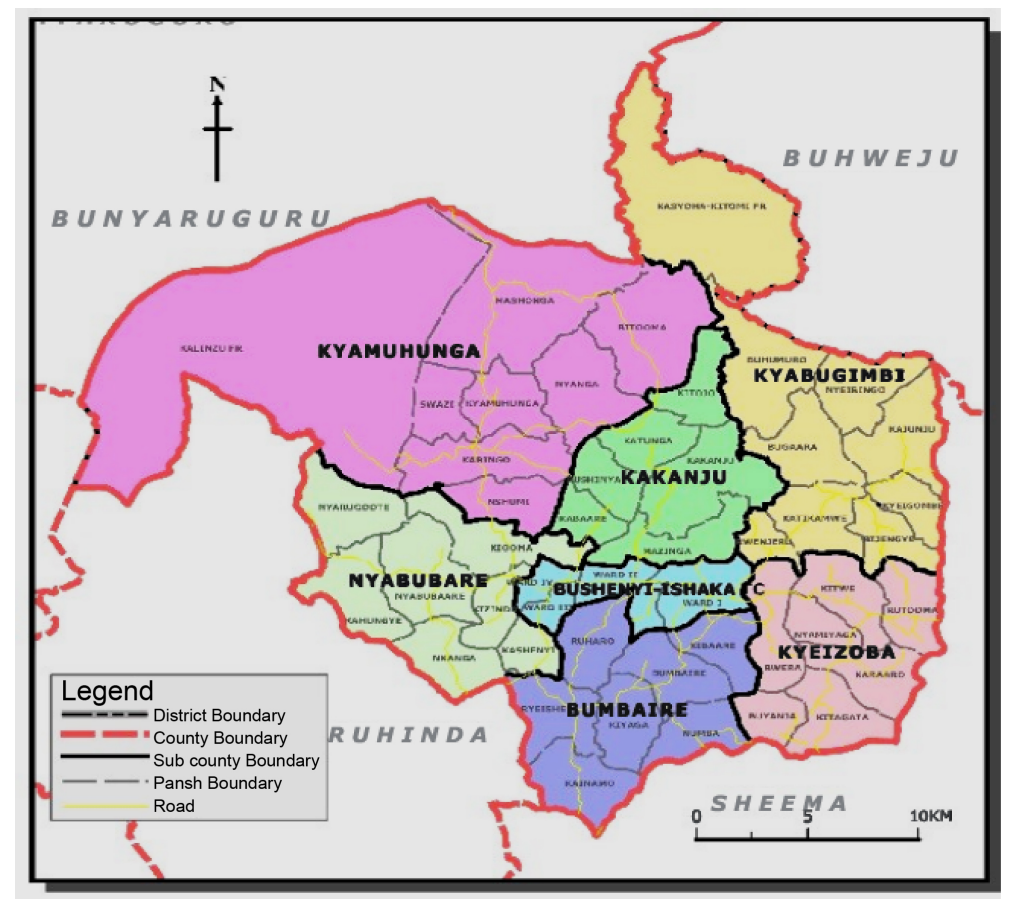

Figure 1. Map of Bushenyi-Ishaka pointed by the black arrow.

\subsection{Study Design}

This study employed cross-sectional study design. Juice samples in restaurants of Bushenyi-Ishaka Municipality were collected and analysed in the laboratory for bacteriological quality.

\section{Sample Size Determination}

The sample size was determined and obtained from table as described by [17].

$\mathrm{N}=$ population size,

$\mathrm{S}=$ sample size.

To calculate the sample of restaurants, all restaurants that prepared the following juices (Mango, Passion fruit, Pineapple and watermelon) were counted to get their total number. For Ishaka 25, Bushenyi 10 and Kizinda 15. According to Krejcie \& Morgan table, for $25(\mathrm{~N})$ populations $24(\mathrm{~s})$ were sampled, for $10(\mathrm{~N})$ populations all $10(\mathrm{~s})$ were sampled and for $15(\mathrm{~N})$ populations $14(\mathrm{~s})$ were sampled.

Therefore, a total of 48 restaurants were sampled for this study.

\subsection{Sample Collection of Unpackaged Fruit Juices}

About 48 restaurants were sampled and the following fruit juices (mango, pineapple, and passion fruit and water melon) were purchased from each restaurant on two different days (Mondays and Wednesdays). The unpackaged fruit juice samples were collected in a $10 \mathrm{ml}$ sterile, dried screw cap universal container labeled with code number [18]. Juices samples were immediately placed in a cooler box containing ice packs to maintain cold chain temperature of about 
$4^{\circ} \mathrm{C}$ and were transported to Microbiology laboratory KIUTH for bacteriological analysis [19].

\subsection{Total Viable Count}

Total viable counts (TVC) of the fruit juices collected were determined by pour plate technique using nutrient agar media (Difco, USA) as described by [19]. The samples were serially diluted as follows: $\left(10^{-1}\right.$ to $\left.10^{-10}\right)$ using a sterile physiological saline, $1 \mathrm{ml}$ of the juice sample was added into $9 \mathrm{ml}$ of physiological saline as the primary dilution of $1: 10,1 \mathrm{ml}$ was then removed and transferred into the next test tube to give a dilution of $1: 100$ and $1 \mathrm{ml}$ was transferred into the third test tube to give a dilution of 1:1000. The aliquots of $1 \mathrm{ml}$ were added into each pre-labeled Petri dish with a code number according to the type of juice and dilution factor. Each of the juice was plated in triplicate of 1:10, 1:00 and 1:1000 respectively aliquots of $1 \mathrm{ml}$ were added into each pre-labelled Petri dish with code number according to the type of juice. A molten sterilized nutrient agar cooled to $45^{\circ} \mathrm{C}$ and poured into each of the Petri-dishes containing the sample aliquot. The plates were swirled to mix the molten agar with the sample and the plates left on the bench for 30 minutes to solidify at room temperature. The agar plates were then incubated at $37^{\circ} \mathrm{C}$ for $18-24$ hours. After incubation, all plates' colonies were counted for all different dilution made and the colony-forming units per $\mathrm{ml}(\mathrm{CFU} / \mathrm{ml})$ of total viable count (TVC) were calculated using standard formula as below to get the total viable count; colonies of less than 10 were regarded as too few to count and more than 300 as too many to count [19].

$$
\mathrm{CFU} / \mathrm{ml}(\mathrm{TVC})=\text { colony counted } \times \frac{1}{\mathrm{dl}} \div \frac{1}{\operatorname{vol} \text { plated }(\mathrm{ml})}
$$

\subsection{Total Coliform Count}

Total Coliform Count was done using MacConkey's agar (Thermo fisher Scientific USA) by pour plate technique. A serial dilution $\left(10^{-1}\right.$ to $\left.10^{-10}\right)$ of the unpackaged fruit juice samples were made with sterile physiological saline. $1 \mathrm{ml}$ of the juice sample was added into $9 \mathrm{ml}$ of physiological saline as the primary dilution of $1: 10,1 \mathrm{ml}$ was then removed and transferred into the next test tube to give a dilution of 1:100 and $1 \mathrm{ml}$ was transferred into the third test tube to give a dilution of 1:1000. The aliquots of $1 \mathrm{ml}$ were added into each pre-labeled Petri dish with a code number according to the type of juice and dilution factor. Each of the juice was plated in triplicate of $1: 10,1: 00$ and 1:1000 respectively aliquots of $1 \mathrm{ml}$ transferred into each pre-labelled Petri dish. Molten MacConkey agar cooled to $45^{\circ} \mathrm{C}$ was then poured in each of the Petri-dishes containing the sample, the plates were swirled to mix the sample with the agar and then left on the bench to solidify. Plates were incubated at $37^{\circ} \mathrm{C}$ for $18-24$ hours. After incubation, all lactose fermenting colonies that appeared pink were counted as part of the total coliforms in the juice sample and the counts were expressed as total co- 
liform colony-forming units per $\mathrm{ml}(\mathrm{CFU} / \mathrm{ml})$; colonies of less than 10 were regarded as too few to count and more than 300 as too many to count [20]. This was calculated using standard formula as below to get the total coliform count $/ \mathrm{ml}$.

$$
\mathrm{CFU} / \mathrm{ml}=\text { colony counted } \times \frac{1}{\mathrm{dl}} \div \frac{1}{\operatorname{vol} \text { plated }(\mathrm{ml})}
$$

\section{Results}

The study showed that levels of bacterial contamination (5.2 - $5.4 \log \mathrm{cfu} / \mathrm{ml})$ were consistent in all the juice samples collected [Figure 2]. Levels of bacterial contamination are in unpacked juices in Bushenyi district. Contamination on day 1 and day 7 was lowest in mangoes for Ishaka samples (A1) and (A2), for passion in Kizinda (B1) and (B2), in pineapples showed no differences (C1) and (C2) while for watermelon it was lowest in Ishaka samples (D1) and (D2). Different superscripts represent significant differences $(\mathrm{p}<0.05)$.

The total coliform counts were found to be in the range of $4.9-5.3 \log \mathrm{cfu} / \mathrm{ml}$ [Figure 3]. Coliforms were highest in mango juice than all juices at any given time. On pineapple juice, only Bushenyi juice samples had significantly low coliform counts [Figure 3]. Total coliform counts in mango (A1) and (A2), passion (B1) and (B2), pineapple (C1) and (C2) and watermelon juice (D1) and (D2) on day 1 and day 7.

The multiple comparison (Table 1) showed a significantly difference with pineapple and water melon juices of Ishaka and Bushenyi at significance level of $\mathrm{p}$ value $<0.05$.

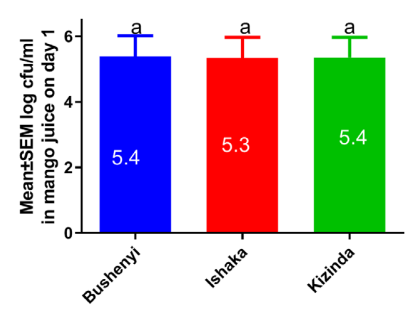

(A1)

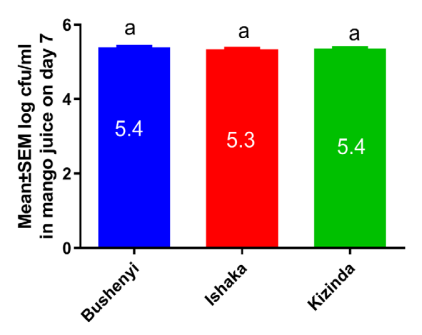

(A2)

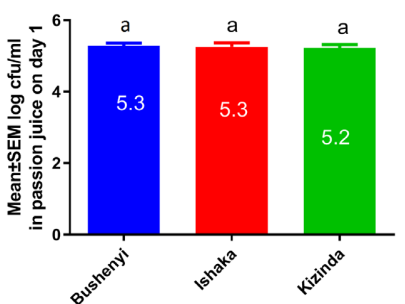

(B1)

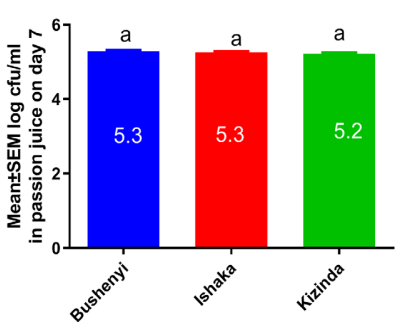

(B2)

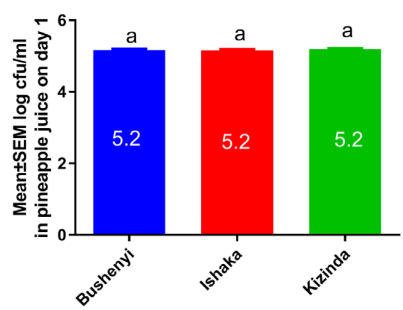

(C1)

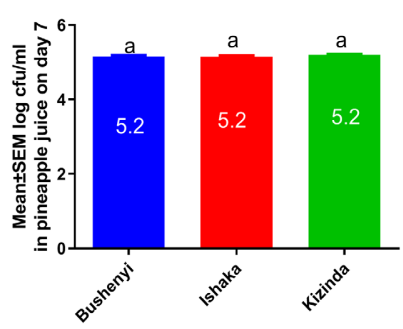

(C2)

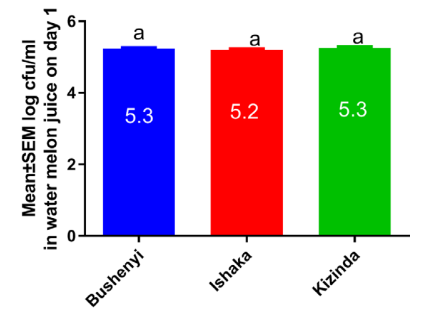

(D1)

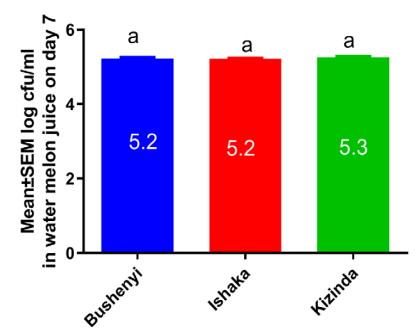

(D2)

Figure 2. Total viable count of unpackaged fruit juice. Keys: - $(\mathrm{A} 1)=$ mango juice day $1 ;(\mathrm{A} 2)=$ mango juice day $2:(\mathrm{B} 1)=$ passion juice day $1 ;(B 2)=$ passion juice day $2:(C 1)$ = pineapple juice day $1 ;(C 2)=$ pineapple juice day $2:(D 1)=$ water melon juice day 1 ; $(\mathrm{D} 2)=$ water melon juice day 2 : Blue $=$ Bushenyi; Red $=$ Ishaka; Green $=$ Kizinda. 


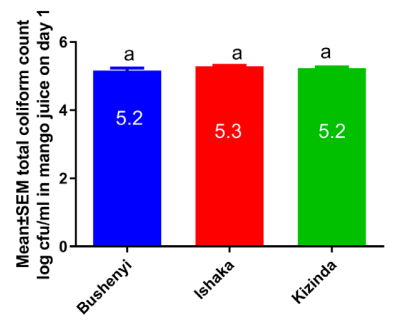

(A1)

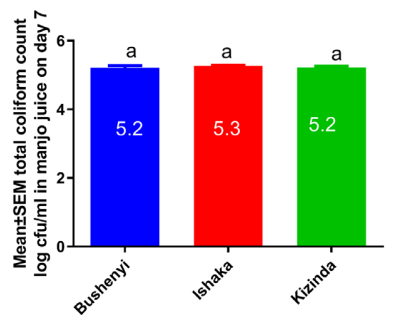

(A2)

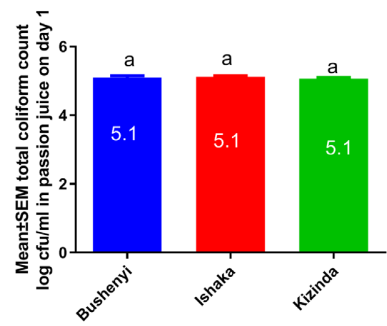

(B1)

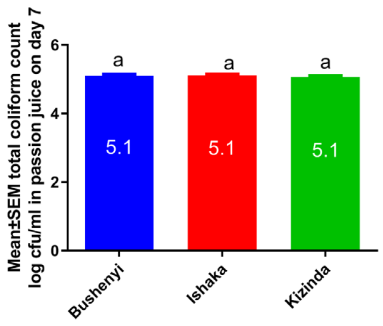

(B2)

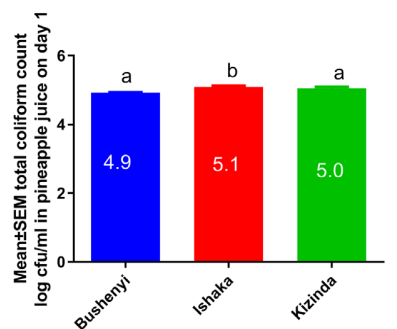

(C1)

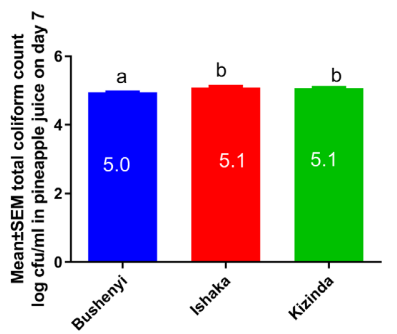

(C2)

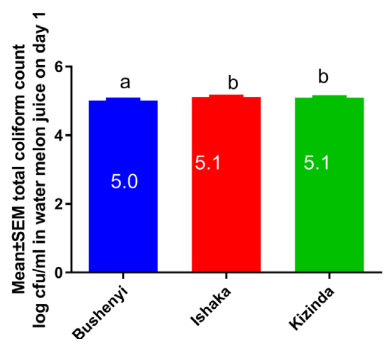

(D1)

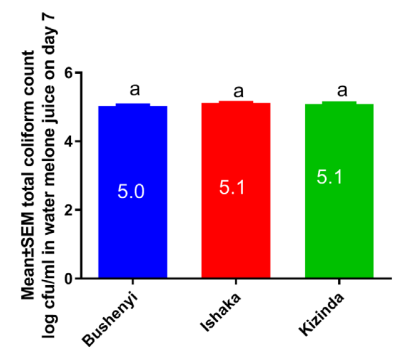

(D2)

Figure 3. Total coliform count of unpackaged fruit juice. Keys: $(A 1)=$ mango juice day $1 ;(A 2)=$ mango juice day 2 : (B1) = passion juice day $1 ;(B 2)=$ passion juice day $2:(C 1)=$ pineapple juice day $1 ;(C 2)=$ pineapple juice day $2:(D 1)=$ water melon juice day $1 ;(\mathrm{D} 2)=$ water melon juice day 2 : Blue = Bushenyi; Red = Ishaka; Green $=$ Kizinda.

Table 1. Multiple comparisons test on total bacterial count and coliform counts in mango, passion, pineapple and watermelon juices of Bushenyi.

\begin{tabular}{|c|c|c|c|c|}
\hline \multirow{2}{*}{ Tukey's multiple comparisons test } & \multicolumn{4}{|c|}{ Adjusted P Value } \\
\hline & Mango & Passion & Pineapple & Water melon \\
\hline \multicolumn{5}{|l|}{ Day 1} \\
\hline Bushenyi vs. Ishaka & 0.9225 & 0.7907 & 0.9676 & 0.7086 \\
\hline Bushenyi vs. Kizinda & 0.9729 & 0.2933 & 0.7689 & 0.9011 \\
\hline Ishaka vs. Kizinda & 0.9871 & 0.4989 & 0.503 & 0.3371 \\
\hline \multicolumn{5}{|l|}{ Day 7} \\
\hline Bushenyi vs. Ishaka & 0.2083 & 0.7242 & 0.9591 & 0.8476 \\
\hline Bushenyi vs. Kizinda & 0.5783 & 0.2198 & 0.6972 & 0.8376 \\
\hline Ishaka vs. Kizinda & 0.7699 & 0.4467 & 0.3979 & 0.395 \\
\hline \multicolumn{5}{|l|}{ Day 1} \\
\hline Bushenyi vs. Ishaka & 0.1162 & 0.9431 & $0.0055^{*}$ & $0.0341^{*}$ \\
\hline Bushenyi vs. Kizinda & 0.5716 & 0.8671 & 0.0932 & 0.2083 \\
\hline Ishaka vs. Kizinda & 0.5651 & 0.5855 & 0.5529 & 0.7198 \\
\hline \multicolumn{5}{|l|}{ Day 7} \\
\hline Bushenyi vs. Ishaka & 0.5822 & 0.9482 & $0.0064^{*}$ & $0.0540^{*}$ \\
\hline Bushenyi vs. Kizinda & 0.9867 & 0.8955 & 0.0750 & 0.3208 \\
\hline Ishaka vs. Kizinda & 0.6278 & 0.6434 & 0.6714 & 0.6556 \\
\hline
\end{tabular}

Key: ${ }^{*}=$ significance values. 
The study showed that a majority of participants were females (58.3\%) and many practiced hand washing at their business. Majority had tertiary education qualification (60.4\%), acquired the fruits from the markets (97.9\%), use tap water $(85.4 \%)$, extract the juice using a blender (97.9\%), had good general level of cleanness $(70.8 \%)$, and had juice making materials which were fairly clean (54.2\%) as shown in Table 2.

\section{Discussion}

This study assessed the bacteriological quality of unpackaged juice (mango, passion fruit, and pineapple, and watermelon) which are commonly served in restaurants of Bushenyi-Ishaka Municipality. This study collected the juice samples in duplicate day 1 and day 7 [Figure 2 \& Figure 3] and this was to ascertain the differences in the level of bacterial load and coliforms within a week. The study showed that levels of bacterial contamination ranges between $5.2-5.4 \log \mathrm{cfu} / \mathrm{ml}$ and were consistent in all the juice samples collected during the study period. In addition, no significant differences were found in the bacterial contaminations on day 1 and day 7 demonstrating constant levels of bacterial contaminants in the study area [Figure 2]. The level of bacterial contamination in unpackaged juices in Bushenyi Municipality on day 1 and day 7 was lowest in mangoes for Ishaka samples, for passion in Kizinda and in pineapples with no significant differences while for watermelon it was lowest in Ishaka samples.

The higher bacterial load recorded in mango juice was due to sweetness of the ripped mango fruit used in juice preparation which provides a suitable environment for bacterial growth as sweetness indicates the presence of sugar in the juice. Also, this could be because most of the people in Bushenyi and Kizinda areas uses springs water sources which is not protected and opened to environmental contamination. Constant bacterial contamination of passion fruit juice in both areas of Bushenyi, Ishaka, and Kizinda was observed with no significant differences on both day 1 and day 7 [Figure 2]. This study observed differences in the total bacterial count of watermelon juice on day 1 and day 7 in Bushenyi. There is higher level of bacterial contamination of all unpackaged juice served in the restaurants above the reference standard of $4 \log \mathrm{CFU} / \mathrm{ml}$. The high level of bacterial count in this study can be compared with a study by [21], who reported a higher level of total bacteria to load in mango and other juices tested but observed the lowest total bacterial load in Malta juice. [6], reported the highest level of bacterial load in juice samples tested in his study. Although, the juices tested in their study was different from the ones tested in this study except for mango juices which according to their study had a lower total bacterial count compared to this study and this was because the mango juice tested in their study was from a packed bottle which has minimal entry of oxygen into the bottle of juice and this in turned, reduced the viability of the bacterial load presence in the juice. 
Table 2. Risk factors to bacterial contamination of unpackaged fruit juice in selected restaurants of Bushenyi-Ishaka Municipality.

\begin{tabular}{|c|c|c|c|c|c|}
\hline \multirow{3}{*}{ Parameter } & \multicolumn{5}{|c|}{ Frequency of participants who practice hand washing } \\
\hline & \multirow[t]{2}{*}{ Variables } & \multicolumn{3}{|c|}{ and disinfectant } & \multirow[t]{2}{*}{ P-values } \\
\hline & & Fair & Good & Total & \\
\hline \multirow{2}{*}{ Gender } & Female & $1(2.1)$ & $27(56.2)$ & $28(58.3)$ & \multirow{2}{*}{0.393} \\
\hline & Male & $0(0)$ & $20(41.7)$ & $20(41.7)$ & \\
\hline \multirow{3}{*}{ Education } & Primary & $0(0)$ & $3(6.2)$ & $3(6.2)$ & \multirow{3}{*}{0.716} \\
\hline & Secondary & $0(0)$ & $16(33.3)$ & $16(33.3)$ & \\
\hline & Tertiary & $1(2.1)$ & $28(58.3)$ & $29(60.4)$ & \\
\hline \multirow{6}{*}{$\begin{array}{l}\text { Experience in juice } \\
\text { production (years) }\end{array}$} & $<1$ & $0(0)$ & $8(16.7)$ & $8(16.7)$ & \multirow{6}{*}{0.955} \\
\hline & 1 & $1(2.1)$ & $18(37.5)$ & $19(39.6)$ & \\
\hline & 2 & $0(0)$ & $12(25.0)$ & $11(25.0)$ & \\
\hline & 3 & $0(0)$ & $6(12.5)$ & $6(12.5)$ & \\
\hline & 4 & $0(0)$ & $2(4.2)$ & $2(4.2)$ & \\
\hline & 6 & $0(0)$ & $1(2.1)$ & $1(2.1)$ & \\
\hline \multirow{2}{*}{ Sources of fruits } & Own garden & $0(0)$ & $1(2.1)$ & $1(2.1)$ & \multirow{2}{*}{0.883} \\
\hline & Markets & $1(2.1)$ & $46(95.8)$ & 47 (97.9) & \\
\hline \multirow{2}{*}{ Sources of water } & Bottled water & $1(2.1)$ & $6(12.5)$ & $7(14.6)$ & \multirow{2}{*}{$0.014^{*}$} \\
\hline & Tap water & $0(0)$ & $41(85.4)$ & $41(85.4)$ & \\
\hline \multirow{2}{*}{ Extraction method } & Blending & $1(2.1)$ & $46(95.8)$ & $47(97.9)$ & \multirow{2}{*}{0.883} \\
\hline & Boiling & $0(0)$ & $1(2.1)$ & $1(2.1)$ & \\
\hline \multirow{3}{*}{$\begin{array}{l}\text { Preparation setting } \\
\text { minimizes cross } \\
\text { contamination }\end{array}$} & Fair & $0(0)$ & $2(4.2)$ & $2(4.2)$ & \multirow{3}{*}{0.068} \\
\hline & Good & $1(2.1)$ & $44(91.7)$ & $45(93.8)$ & \\
\hline & Very good & $0(0)$ & $1(2.1)$ & $1(2.1)$ & \\
\hline \multirow{2}{*}{$\begin{array}{l}\text { Washing processes of fruits } \\
\text { with clean water }\end{array}$} & Good & $1(2.1)$ & $46(95.80$ & 47 (97.9) & \multirow{2}{*}{0.883} \\
\hline & Very good & $0(0)$ & $1(2.1)$ & $1(2.1)$ & \\
\hline \multirow{2}{*}{$\begin{array}{l}\text { General cleanness of the } \\
\text { handler clothing }\end{array}$} & Fair & $0(0)$ & $14(29.3)$ & $14(29.3)$ & \multirow{2}{*}{0.517} \\
\hline & Good & $1(2.1)$ & $33(68.8)$ & $34(70.8)$ & \\
\hline \multirow{3}{*}{$\begin{array}{l}\text { Protection of juices from } \\
\text { environmental } \\
\text { contamination }\end{array}$} & Fair & $0(0)$ & $1(2.1)$ & $1(2.1)$ & \multirow{3}{*}{0.967} \\
\hline & Good & $1(2.1)$ & $44(91.7)$ & $45(93.8)$ & \\
\hline & Very good & $0(0)$ & $2(4.2)$ & $2(4.2)$ & \\
\hline \multirow{2}{*}{$\begin{array}{l}\text { Juice storage facility availa- } \\
\text { ble }\end{array}$} & Good & $1(2.1)$ & $42(87.5)$ & $43(89.6)$ & \multirow{2}{*}{0.730} \\
\hline & Very good & $0(0.0)$ & $5(10.4)$ & $5(10.4)$ & \\
\hline \multirow{2}{*}{$\begin{array}{l}\text { Location of juice } \\
\text { selling point }\end{array}$} & Fair & $0(0)$ & $2(4.2)$ & $2(4.2)$ & 0.833 \\
\hline & Good & $1(2.1)$ & $45(93.8)$ & $46(95.8)$ & 0.835 \\
\hline & Fair & $0(0)$ & $26(54.2)$ & $26(54.2)$ & \\
\hline $\begin{array}{l}\text { Means of cleaning } \\
\text { serving utensils }\end{array}$ & Good & $1(2.1)$ & $16(33.3)$ & $17(35.4)$ & 0.394 \\
\hline & Poor & $0(0)$ & $5(10.4)$ & $5(10.4)$ & \\
\hline
\end{tabular}

Key: ${ }^{*}=$ significance values. 
Coliform bacteria in this study were found to be in the range of $4.9-5.3 \log$ $\mathrm{CFU} / \mathrm{ml}$ [Figure 3] and were highest in mango juice than all juices at any given time and its presence indicates a fecal contamination from water use in juice preparation and cleaning of utensils. On pineapple juice, only Bushenyi juice samples had significantly low coliform counts [Figure 3]. The coliform bacteria in mango, passion, pineapple, and watermelon juice on day 1 and day 7 [Figure 3] is suggestive of health safety dangers to consumers of unpackaged juices served in restaurants of Bushenyi-Ishaka Municipality. These coliform bacteria are known to originate from the gastrointestinal tract which is their normal habitat; these coliform bacteria are also known to be indicators for fecal contamination especially of water and this water is mostly added to juice served in restaurants.

The presence of coliform bacteria in the juice samples above the set standards indicates the potential presence of pathogenic bacteria as well which posed a health threat to consumers of these juices. The higher level of contamination with coliform bacteria in this study is indicated it is a universal problem as a study from India also revealed the highest coliform bacteria in all juices tested [22]. Also in Bangladesh, a higher coliform bacteria load was recorded in all juices tested [23]. A study in Nigeria also reported a higher mean of total coliform bacteria count [24].

In Uganda, a study of vended bottled drinks reported a higher level of contamination with E. coli which is a coliform bacteria [25]. The higher level of contamination with coliform bacteria reported by other researchers and in this study indicated poor handling of juices during preparation and this poses a serious threat to consumers especially in developing countries where access to clean water is scarce [22] in India; [23] in Bangladesh; [24] in Nigeria and [25] in Uganda all reported higher coliform count in their study. The high level of bacterial contamination in this study can be attributed to the 5 "Fs" principles of disease transmission where bacteria are confirmed to be transmitted through fingers, flies, fields, fluids, and food.

The majority of juice producer in this study were females also, majority of juice producers attended their education up to tertiary level followed by secondary level and very few with primary education [Table 2]. The experience of juice producers was in the range of 1 to 6 years with majority having 2 years' experience in juice preparation, followed by 3 -year and 1-year experience respectively [Table 2]. Most of the restaurants owners used purchased fruits from the markets. Majority used tap water while a few purchased purified bottled water (Rwenzori), majority extract the fruit by blending. This study observed that the preparation settings, general cleanness, water used for washing utensils, facilities for storage of juice, location of juice selling point and protection of juice from environmental contamination in this study was observed to be good although, the means of cleaning serving utensils was fair, most of the juice producers used tissue paper to clean serving utensils [Table 2]. 
The observed general cleanness of the juice premises may be due to the continuous awareness on hygiene since, the study was done during the COVID-19 pandemic period and so, the awareness of health safety procedures was fresh in people's memory yet, it does not minimize the level of bacterial contamination observed in the study areas. This could be because majority used tap water for juice preparation which might have been contaminated due to pipe leakage along the channel of distribution before reaching the users. Water is also known to be a vehicle for transmission of enteric pathogens usually contaminated by fecal materials due to poor disposal of human and animal excreta [25].

\section{Conclusion}

This study concludes there is a higher level of bacterial contamination in all juices tested in restaurants of Bushenyi-Ishaka Municipality. The coliform bacteria indicated the presence of fecal materials in water used for juice preparation and cleaning of utensils. Tap water used for juice making may be contaminated along the distributing pipes due to breakage hence, contamination of water occurred in the distributing pipe before reaching the point of used.

\section{Recommendations}

This study observed contamination with fecal coliform bacteria to be a public health concern in the study areas and called for intensify health education among juice producers to observe safety steps in juice preparation as this would minimize bacterial contamination to acceptable standards of Uganda and WHO. Water for juice preparation should be boiled before addition to juice as this would minimized bacterial contamination and killed most of the fecal coliform bacteria that might have contaminated the water.

Water cooperation personnel should increase surveillance by engaging the community to report any pipe breakage for urgent repairs to avoid contamination of the pipe borne water.

\section{Conflict of Interest}

The authors declared no conflict of interest whatsoever in respect to this study.

\section{Funding}

This study has no grant from any source, all materials used in this study were sponsored by the principal investigator.

\section{Author's Contribution}

T.P conceptualized the study, collected the data, carried out the laboratory work and interpreted the findings and also, write the primary manuscript. S.M and A.T supervised and performed editing of the manuscript for suitability of publication. 


\section{Acknowledgement}

The researchers acknowledged the district health officer (DHO) Bushenyi district for permission to carry out the study in the selected areas. We acknowledged the restaurants owners for their time and consent to use their juices for this study. We are grateful to Kampala International University Teaching Hospital Microbiology Laboratory for allowing this study to take place in their laboratory.

\section{References}

[1] Mortuza, T. (2016) Isolation and Identification of Microbes from Various Fruit Juices Made and Sold for Immediate Consumption at Home and in the Market of Dhaka City, BRAC UNIVERSITY DHAKA.

[2] Aneja, K.R., Dhiman, R., Aggarwal, N.K., Kumar, V. and Kaur, M. (2014) Microbes Associated with Freshly Prepared Juices of Citrus and Carrots. International Journal of Food Science, 2014, Article ID: 408085. https://doi.org/10.1155/2014/408085

[3] Centre for Food Safety (2014) Microbiological Guidelines for Food. Food and Environmental Hygiene Department, Hong Kong (China), 46p.

[4] Mohd Nawawee, N.S., Abu Bakar, N.F. and Zulfakar, S.S. (2019) Microbiological Safety of Street-Vended Beverages in Chow Kit, Kuala Lumpur. International Journal of Environmental Research and Public Health, 16, Article No. 4463. https://doi.org/10.3390/ijerph16224463

[5] UNBS (Uganda National Bureau of Standards) (2015) Uganda Standards Catalogue. Uganda National Bureau of Standards, Kampala.

[6] Majibur, M. (2013) Microbiological Study of Vendor and Packed Fruit Juices Locally Available in Dhaka City, Bangladesh. International Food Research Journal, 20, 1011-1015.

[7] Sharma, P.U. (2013) Original Research Article Bacteriological Analysis of Street Vended Fruit Juices Available in Vidarbha. International Journal of Current Microbiology and Applied Sciences, 2, 178-183.

[8] Vojdani, J.D., Beuchat, L.R. and Tauxe, R.V. (2008) Juice-Associated Outbreaks of Human Illness in the United States, 1995 through 2005. Journal of Food Protection, 71, 356-364. https://doi.org/10.4315/0362-028X-71.2.356

[9] Ahmed, M.S.U., Nasreen, T., Feroza, B. and Parveen, S. (2009) Microbiological Quality of Local Market Vended Freshly Squeezed Fruit Juices in Dhaka City, Bangladesh. Bangladesh Journal of Scientific and Industrial Research, 44, 421-424. https://doi.org/10.3329/bjsir.v44i4.4591

[10] Tambekar, D.H., Murhekar, S.M., Dhanorkar, D.V., Gulhane, P.B. and Dudhane, M.N. (2009) Microbial Quality and Safety of Street Vended Fruit Juices: A Case Study of Amravati City. Internet Journal of Food Safety, 10, 72-76.

[11] Rahman, T., Hasan, S. and Noor, R. (2011) An Assessment of Microbiological Quality of Some Commercially Packed and Fresh Fruit Juice Available in Dhaka City: A Comparative Study. Stamford Journal of Microbiology, 1, 13-18. https://doi.org/10.3329/sjm.v1i1.9097

[12] Ketema, T., Gaddisa, T. and Bacha, K. (2008) Microbiological Safety of Fruit Juices Served in Cafes/Restaurants, Jimma Town, South West, Ethopia. Ethiopian Journal of Health Sciences, 18, 98-103.

[13] Mahale, D.P., Khade, R.G. and Vaidya, V.K. (2008) Microbiological Analysis of 
Street Vended Fruit Juices from Mumbai City, India. Internet Journal of Food Safety, 10, 31-34.

[14] Kaddumukasa, P.P., Imathiu, S.M., Mathara, J.M. and Nakavuma, J.L. (2019) Bacterial Contamination of Selected Fruits, Fresh Juice Contact Surfaces and Processor's Hands: Potential Risk for Consumers' Health in Uganda. Journal of Food Science and Nutrition Research, 2, 199-213. https://doi.org/10.26502/jfsnr.2642-11000020

[15] UNBS (Uganda National Bureau of Standards) (2010) The Analysis of the Nutrition Situation in Uganda May 2010. Uganda National Bureau of Standards, Kampala.

[16] UBOS (Uganda Bureau of Statistics) (2014) National Population and Housing Census 2014: Provisional Results. Uganda Bureau of Statistics, Kampala.

[17] Krejcie, R.V and Morgan, D.W. (1970) Determining Sample Size for Research Activities. Educational and Psychological Measurement, 30, 607-610. https://doi.org/10.1177/001316447003000308

[18] ISS (2017) International Scientific Supplies. International Scientific Supplies Ltd., Bradford, 57.

[19] Campbell, S.G. and Byersdorfer, A.L. (2015) Standard Operating Policy/Procedure Standard Bacterial Plate Count. United States Department of Agriculture, Center for Veterinary Biologics, Ames, 1-16.

[20] Bhagra, S., Singh, D., Sood, A. and Kanga, A. (2017) Bacteriological Profile of Water Samples in and Around Shimla Hills: A Study from the Sub Himalayan Region Bacteriological Profile of Water Samples in and around Shimla Hills: A Study from the Sub Himalayan Region. International Journal Of Community Medicine And Public Health, 6, 1966-1971. https://doi.org/10.18203/2394-6040.ijcmph20172158

[21] Fatema, K., Rahman, S., Ahmed, S. and Datta, S. (2016) Microbiological Quality Assessment of Handmade Juice in Street of the Dhaka City. Allergy Drugs and Clinical Immunology, 1, Article No. 101.

[22] Srinath, D. (2017) Microbiological Quality Analysis of Street Vended Fruit Juices in Hyderabad City, India. International Journal of Pure \& Applied Bioscience, 5, 13141317. https://doi.org/10.18782/2320-7051.5441

[23] Akter, S., Zubair, A., Khan, S.H., Bari, L., Huq, A. and Rashid, M.A. (2017) Identification and Quantification of Sodium Benzoate in Different Brands of Mango Juices Available in Tangail Region, Bangladesh. Bangladesh Pharmaceutical Journal, 20, 20-26. https://doi.org/10.3329/bpj.v20i1.32089

[24] Bello, O., Temitope, B.K., Muibat, F.O. and Oluwadun, A. (2014) Microbiological Quality of Some Locally-Produced Fruit Juices in Ogun State, South Western Nigeria. E3 Journal of Microbiology Research, 2, 1-8.

[25] Mugampoza, D., Byarugaba, G.W.B., Nyonyintono, A., Nakitto, P., Campus, B. and Kingdom, U. (2013) Occurrence of Escherichia coli and Salmonella spp. in StreetVended Foods and General Hygienic and Trading Practices in Nakawa Division, Uganda. American Journal of Food Science and Nutrition, 3, 167-175. 